\title{
Non-classical genomic estrogen receptor (ER)/specificity protein and ER/activating protein-1 signaling pathways
}

\author{
Stephen Safe ${ }^{1,2}$ and Kyoungkim Kim ${ }^{2}$ \\ ${ }^{1}$ Department of Veterinary Physiology and Pharmacology, Texas A\&M University, College Station, Texas 77843-4466, USA \\ ${ }^{2}$ Institute of Biosciences and Technology, Texas A\&M University Health Science Center, Houston, Texas 77030-3303, USA \\ (Correspondence should be addressed to S Safe; Email: ssafe@cvm.tamu.edu)
}

\begin{abstract}
$17 \beta$-Estradiol binds to the estrogen receptor (ER) to activate gene expression or repression and this involves both genomic (nuclear) and non-genomic (extranuclear) pathways. Genomic pathways include the classical interactions of ligand-bound ER dimers with estrogen-responsive elements in target gene promoters. ER-dependent activation of gene expression also involves DNA-bound ER that subsequently interacts with other DNA-bound transcriptions factors and direct ER-transcription factor (protein-protein) interactions where ER does not bind promoter DNA. Ligand-induced activation of ER/specificity protein (Sp) and ER/activating protein-1 [(AP-1); consisting of jun/fos] complexes are important pathways for modulating expression of a large number of genes. This review summarizes some of the characteristics of ER/Sp- and ER/AP-1mediated transactivation, which are dependent on ligand structure, cell context, ER-subtype (ER $\alpha$ and ER $\beta$ ), and Sp protein (SP1, SP3, and SP4) and demonstrates that this non-classical genomic pathway is also functional in vivo.
\end{abstract}

Journal of Molecular Endocrinology (2008) 41, 263-275

\section{Ligand-dependent activation of estrogen receptor (ER)/specificity protein (SP)}

\section{Introduction}

SP1 was the first transcription factor identified in the early 1980s (Dynan \& Tjian 1983, 1985, Briggs et al. 1986) and is a member of the $\mathrm{Sp} /$ Krüppel-like family (KLF) of at least 25 transcription factors (Suske et al. 2005). Sp/KLF proteins have highly variable modular structures in their $\mathrm{N}$-terminal domains and are characterized by three $\mathrm{C}_{2} \mathrm{H}_{2}-$ type zinc fingers in their C-terminal domain, which are required for their sequence-specific DNA binding (Philipsen \& Suske 1999, Black et al. 2001, Bouwman \& Philipsen 2002). Sp/KLF family members recognize GC/ GT boxes in promoter regions of mammalian and viral genes, and the consensus SP1 binding site $5^{\prime}-(\mathrm{G} /$ T)GGGCGG (G/A) (G/A) (C/T)-3' interacts with most $\mathrm{Sp} / \mathrm{KLF}$ proteins. SP2 is the major exception among Sp proteins and this protein binds weakly to consensus GC-rich sites but binds with higher affinity to a $5^{\prime}$ GGGCGGGAC-3' motif (Moorefield et al. 2004). Interactions of $\mathrm{Sp} / \mathrm{KLF}$ transcription factors with GC-rich promoters have primarily been investigated with SP1 and SP3 proteins that are ubiquitously expressed in normal tissues and highly overexpressed in tumors and cancer cells (Philipsen \& Suske 1999, Black et al. 2001, Bouwman \& Philipsen 2002, Suske et al. 2005). Both proteins bind the consensus 'SP1' binding sequence and also a large number of non-consensus sequences with variable affinities in in vitro binding studies. However, the importance of specific GC-rich sequences in a gene promoter in mediating transactivation is highly variable and dependent on cell context and the relative expression of nuclear coactivators and other cofactors.

Sp proteins play a critical role in several key biological processes including cellular differentiation, proliferation, survival, and angiogenesis (Philipsen \& Suske 1999, Black et al. 2001, Bouwman \& Philipsen 2002), and SP1, SP3, and SP4 knockout animals are either embryolethal or their offspring exhibit severe abnormalities (Supp et al. 1996, Marin et al. 1997, Gollner et al. 2001 a,b). By contrast, expression of SP1 and possibly other Sp proteins is relatively low in mature animals and decreases with age (Ammendola et al. 1992, Oh et al. 2007). Several reports show that SP1 and other SP proteins are overexpressed in tumors and cancer cells (Zannetti et al. 2000, Shi et al. 2001, Chiefari et al. 2002, Wang et al. 2003, Hosoi et al. 2004, Yao et al. 2004, Lou et al. 2005, Safe \& Abdelrahim 2005, Kanai et al. 2006), and SP1 overexpression in gastric

DOI: 10.1677/JME-08-0103 Online version via http://www.endocrinology-journals.org 
tumors is a negative prognostic factor for disease-free survival. For example, Lou et al. (2005) reported that transformation of fibroblasts resulted in an 8- to 18-fold increase in SP1 protein expression, and in xenograft experiments, SP1 expression was required for tumor growth. Not surprisingly, recent studies showed that SP1, SP3, and SP4 were highly overexpressed in various cancer cell lines including both ER-positive and ER-negative breast cancer cells (Safe \& Abdelrahim 2005, Mertens-Talcott et al. 2007), and several reports demonstrate that SP1 and other Sp proteins play an important role in regulation of $17 \beta$-estradiol $\left(\mathrm{E}_{2}\right)$-dependent genes in breast cancer cell lines and in many other cell-types (Safe 2001, Safe \& Kim 2004).

\section{Role of Sp proteins in hormonal activation of genes}

\section{$E R / S p$ modulation of genes: DNA-dependent interaction of $E R$ and Sp proteins}

Many $\mathrm{E}_{2}$-responsive gene promoters contain both GC-rich estrogen-responsive element (ERE) and ERE half sites $\left(\mathrm{ERE}^{1 / 2}\right)$ that cooperatively interact to activate expression of genes. The uteroglobin promoter contains a non-consensus ERE ( -263 to -251$)$ that binds ER $\alpha$; however, hormonal activation of this gene and related promoter constructs involves interaction with both proximal $(-232$ to $-223 ;-200$ to -199$)$ and more distal ( -67 to -60$)$ GC-rich Sp binding sites (Scholz et al. 1998). Although DNA-protein binding studies have not identified an ER $\alpha /$ Sp complex, both
SP1 and ER $\alpha$ bind individually to the uteroglobin gene promoter oligonucleotide fragments containing the GC-rich and ERE sites respectively. Analysis of the Xenopus vitellogenin A1 promoter has also identified ERE and GC-rich sites separated by $1.8 \mathrm{~kb}$ that are required for hormonal activation of this gene (Batistuzzo de Medeiros et al. 1997). Subsequent studies have identified ERE and GC-rich sites in the estrogen-related receptor and the mouse Slo promoter required for hormonal activation (Liu et al. 2003, Kundu et al. 2007).

Research in this laboratory initially focused on extensive analysis of the cathepsin $\mathrm{D}$ gene promoter that had previously been characterized as an $\mathrm{E}_{2^{-}}$ responsive gene (Cavailles et al. 1993, Augereau et al. 1994, Krishnan et al. 1994, 1995). We identified an $\mathrm{E}_{2}$-responsive sequence in the -199 to -165 region of the promoter that did not contain ERE motifs. Subsequent analysis identified both a non-concensus $\mathrm{ERE}^{1 / 2}$ and GC-rich elements separated by 23 oligonucleotides (Fig. 1) that were $E_{2}$-responsive in transfection assays. Mutation of either the GC-rich or the ERE $1 / 2$ resulted in the loss of hormone activation of this construct. These results coupled with the detection of an ER $\alpha / \mathrm{SP} 1-\mathrm{DNA}$ complex in gel mobility shift assays clearly demonstrated a novel genomic mechanism of ER-dependent transactivation that required cooperative $\mathrm{ER} \alpha / \mathrm{SP} 1$ interactions on the cathepsin D promoter. Subsequent studies in several laboratories confirmed that this DNA-dependent ER/Spmediated pathway was important for activation of multiple genes, including transforming growth factor $\alpha$ (Tgfa), c-myc, heat shock protein 27 (Hspb1), telomerase,

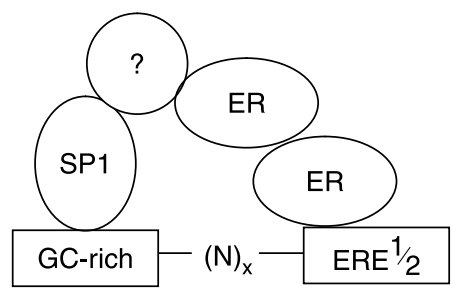

\begin{tabular}{cccc} 
Gene & GC & N & ERE $1 / 2$ \\
\hline Cathepsin D & $(-195)$ GGCGGG & 23 & GGGCA $(-165)$ \\
Hspbl & $(-105)$ GGGCGG & 10 & GGTCA $(-84)$ \\
Tgfa & $(-252)$ GGGCGG & 31 & GGTCA $(-200)$ \\
c-myc & GGCGGG & 16 & GGGCA \\
Telomerase & $(-974)$ GGGCGGG & 3 & TGACC $(-959)$ \\
Mta3 & $(-210)$ CCCCAGCCCC(-200) & 68 & TGACC $(-130)$ \\
PR & $-3^{\prime}(+580)$ CCGCCC & 4 & TGACC $(+571)\left(5^{\prime}\right)$ \\
& $-3^{\prime}(+590)$ CCGCCC & 14 & \\
LrP16 & $-3^{\prime}(229)$ GGGCGGG & 6 & GGTCA $(-247)\left(5^{\prime}\right)$
\end{tabular}

Figure $1 \mathrm{~A}$ summary of $E_{2}$-responsive genes containing functional GC-rich and ERE $1 / 2$ motifs. There is evidence that formation of this complex may contain other proteins. 
progesterone receptor A, metastasis-associated protein 3 (Mta3), and Lpr16 (Dubik \& Shiu 1992, Porter et al. 1996, Petz \& Nardulli 2000, Vyhlidal et al. 2000, Fujita et al. 2004, Zhao et al. 2005, Boggess et al. 2006). Figure 1 illustrates the variety of the GC-rich and ERE $1 / 2$ motifs, their location in promoters and the number of nucleotides separating the two elements. These motifs and their location are highly variable, making it difficult to predict $\mathrm{E}_{2}$-responsiveness from these sequences. Moreover, cell context will also influence whether these motifs will form hormoneresponsive protein-DNA complexes.

\section{$E R / S p$ modulation of genes through interactions of Sp proteins with GC-rich motifs}

Identification of ER $\alpha / S p$-mediated genes. During analysis of the $H s p b 1$ gene promoter, it was observed that after mutation of the proximal ERE $1 / 2$ site, transfection of the resulting GC-rich construct in MCF-7 cells followed by treatment with $\mathrm{E}_{2}$ resulted in the induction of reporter gene activity (Porter et al. 1997). Subsequent studies with the Hsp27 promoter or a promoter containing one or more consensus GC-rich motifs demonstrated that $\mathrm{E}_{2}$ activated ER $\alpha$-dependent gene expression through interactions with GC-rich promoter elements (Porter et al. 1997). The $\mathrm{E}_{2}$-dependent activation of $\mathrm{ER} \alpha / \mathrm{Sp}$ through interactions with GC-rich elements in $\mathrm{E}_{2}$-responsive gene promoters is a novel genomic pathway for both inducing and repressing gene expression and exhibits several unique characteristics that include the following:

1. $\mathrm{ER} \alpha$ directly interacts with the C-terminal DNA-binding domain of SP1, which is a region within SP1 that interacts with a host of other transcription factors including other steroid hormone receptors (Owen et al. 1998, Simmen et al. 1999, Husmann et al. 2000, Lu et al. 2000, Curtin et al. 2001). Interaction of ER $\alpha$ with other Sp proteins have not been well characterized; however, $\mathrm{ER} \alpha$ interacts with multiple domains of SP3 (Stoner et al. 2000). ER $\beta$ interacts with the C-terminal domain of $\mathrm{SP} 1$; however, unlike $\mathrm{ER} \alpha, \mathrm{ER} \beta$ interacts with regions outside this domain (Saville et al. 2000). Interactions between ER and SP1 were ligand-independent.

2. In gel mobility shift assays, a direct formation of ternary $\mathrm{ER} \alpha / \mathrm{Sp}-\mathrm{DNA}$ complexes was not detected. However, $\mathrm{ER} \alpha\left( \pm \mathrm{E}_{2}\right)$ enhanced formation of the Sp-DNA complex and kinetic studies showed that ER $\alpha$ also increased the stability of the SP1-DNA complex.

3. Results of chromatin immunoprecipitation (ChIP) assays showed that $\mathrm{ER} \alpha$ is constitutively associated with $\mathrm{E}_{2}$-responsive GC-rich promoter elements that also bind SP1, SP3, and SP4. Treatment of breast cancer cells with $\mathrm{E}_{2}$ does not appreciably affect $\mathrm{ER} \alpha$ and $\mathrm{Sp}$ interactions with $\mathrm{E}_{2}$-responsive GC-rich promoter sequences; however, changes in co-regulatory proteins may be altered.
After initial characterization of GC-rich promoter sites as targets for $\mathrm{E}_{2}$-dependent transactivation (Porter et al. 1997), studies in this laboratory focused on identifying other genes in breast cancer cells that are activated by ER $\alpha / \mathrm{Sp}$. Genes activated by this genomic pathway include $H s p b 1$, cathepsin D, $c$-fos, retinoic acid receptor $\alpha 1$ (Rara1), adenosine deaminase, IGF-binding protein 4, Bcl2, E2f1, thymidylate synthase, vascular endothelial growth factor $(\operatorname{Veg} f)$, cyclin D1, creatine kinase B, DNA polymerase $\alpha$, carbamoylphosphate synthetase/aspartate carbamyltransferase/dihydroorotase $(C a d)$, ovine oxytocin receptor, and Vegfr2 (Duan et al. 1998, Sun et al. 1998, Dong et al. 1999, Qin et al. 1999, Wang et al. 1999, 2002Xie et al. 1999, 2000, Castro-Rivera et al. 2001, Samudio et al. 2001, Khan et al. 2003, Ngwenya \& Safe 2003, Stoner et al. 2004, Fleming et al. 2006, Higgins et al. 2006, 2008). Subsequent studies in many other laboratories have extended the list of $\mathrm{E}_{2}$-responsive genes regulated by $\mathrm{ER} \alpha / \mathrm{Sp}$ interactions with GC-rich sites and these include folate receptor $\alpha$, estrogen-related receptor $\alpha$, prothymosin $\alpha$, progesterone receptor. prolactin receptor, peptidylarginine deiminase type IV (PADI4), epidermal growth factor receptor (EGFR), kisspeptin 1 (KiSS1), IGF-1 receptor, HOXA10, trefoil factor 1 , vitamin $\mathrm{D}$ receptor, low density lipoprotein receptor, fibulin-1, rat Sk3, and receptor for advanced glycation end products (Briggs et al. 1986, Byrne et al. 2000, Salvatori et al. 2000, Tanaka et al. 2000, Martini \& Katzenellenbogen 2001, Jacobson et al. 2003, Kelley et al. 2003, Schultz et al. 2003, Bardin et al. 2005, Sun et al. 2005, Dong et al. 2006, 2007, Maor et al. 2006, Li et al. 2007, Martin et al. 2007). These genes are $\mathrm{E}_{2}$-responsive in several different cell lines and promoter analysis showed that $\mathrm{E}_{2}$ not only induces gene expression through GC-rich motifs but also other sites in the promoters that may be activated by genomic and/or non-genomic pathways. For example, the $c$-fos, Bcl2 and cyclin D1 genes all contain $\mathrm{E}_{2}$-responsive GC-rich sites; however, induction by $\mathrm{E}_{2}$ also involves non-genomic $\mathrm{E}_{2}$-dependent activation of MAPK/PI3K (fos), and cAMP/PKA (Bcl2 and cyclin D1; Duan et al. 1998, 2001, 2002, Dong et al. 1999, Castro-Rivera et al. 2001; Fig. 2). It is also possible that activation of nongenomic pathways also activates ER/Sp-dependent genes. A recent paper on the induction of PADI4 by $\mathrm{E}_{2}$ in MCF-7 cells also demonstrates the role of multiple hormone-dependent pathways for transactivation (Dong et al. 2007). This gene contains two upstream ERE motifs that bind $\mathrm{ER} \alpha$ and contribute to induced gene expression; however, the proximal regions of the gene contains GC-rich, AP-1, and NF-YA sites that are important for PADI4 gene expression (Fig. 3). Deletion analysis and RNA interference studies suggest that although ER $\alpha / \mathrm{SP} 1$ (and not $\mathrm{ER} \alpha / \mathrm{SP} 3$ ) contributes to $\mathrm{E}_{2}$-induced gene expression, interactions of $\mathrm{ER} \alpha$ and/or SP1 with NF-YA and AP-1 are also involved in 


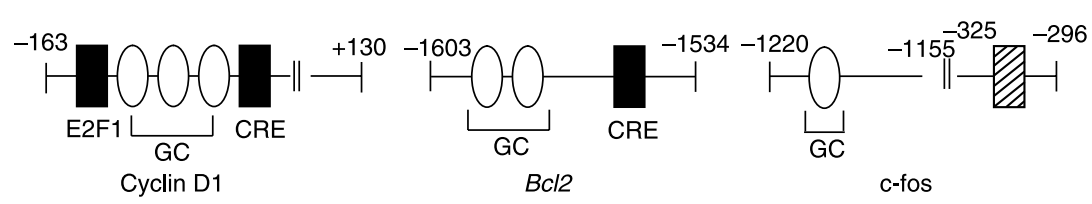

Figure 2 Hormonal activation of cyclin D1, Bcl2, and $c$-fos in breast cancer cells. In addition to GC-rich sites activated by $\mathrm{ER} / \mathrm{Sp}, \mathrm{E}_{2}$-dependent activation of non-genomic cAMP/PKA (cyclin D1 and Bcl2), and MAPK/PI3K(c-fos) pathways were also identified.

the induction of PADI4 (Dong et al. 2007). Similar results were observed for induction of the human prolactin receptor that involved interactions of $\mathrm{ER} \alpha / \mathrm{Sp}$ with C-EBP $\beta$ (Dong et al. 2006) (Fig. 3).

Studies in this laboratory show that cell context plays a critical role in the molecular mechanisms of hormone-dependent transactivation. $\mathrm{E}_{2}$ induced E2F1 gene expression in MCF-7 cells and the minimal $\mathrm{E}_{2^{-}}$ responsive region of the $\mathrm{E} 2 \mathrm{~F} 1$ promoter contained three consecutive GC-rich sites and two CCAAT binding sites (Wang et al. 1999, Ngwenya \& Safe 2003). Promoter analysis showed that the GC-rich or CCAAT sites alone were not $\mathrm{E}_{2}$ responsive in transient transfection studies and that hormone-responsiveness required at least one upstream GC-rich site and both CCAAT elements (Fig. 4). DNA binding studies show that ER $\alpha$ and SP1 enhance NF-YA binding to the CCAAT sites and that hormone-induced transactivation in MCF-7 cells is associated with an $\mathrm{ER} \alpha / \mathrm{Sp} / \mathrm{NF}-\mathrm{YA}$ complex. Induction of E2F1 in ZR-75 (ER-positive) breast cancer cells involves the same response elements; however, the GC-rich sites are independently activated by $\mathrm{ER} \alpha / \mathrm{Sp}$, and NF-YA is induced by $\mathrm{E}_{2}$ through non-genomic ER-dependent activation of cAMP/PKA.

One of the most striking cell context-dependent differences in hormonal modulation of gene expression by $\mathrm{ER} \alpha / \mathrm{Sp}$ is associated with expression of Vegfr2 in ZR-75 and MCF-7 cells (Higgins et al. 2006, 2008). Vegf and Vegfr2 are critical angiogenic genes that contain proximal GC-rich sites required for basal and hormone-dependent expression (Fig. 5). Initial studies showed that $\mathrm{E}_{2}$ induced Vegfr2 expression in ZR-75 cells and this involved two proximal GC-rich sites at -58 and -54 . By contrast, $\mathrm{E}_{2}$ decreased expression of Vegfr 2 in MCF-7 cells and promoter analysis showed that the same promoter elements required for $\mathrm{E}_{2}$-induced transactivation in ZR-75 were required for suppressed expression of Vegfr2 in MCF-7 cells. The major cell context-dependent differences were observed in ChIP assays where $\mathrm{E}_{2}$ induced recruitment of the co-repressors NCoR and SMRT to the Vegfr2 promoter in MCF-7 but not in ZR-75 cells. In the latter cell line, treatment with $\mathrm{E}_{2}$ increased recruitment of the coactivator SRC-3 to the GC-rich promoter, whereas this was not observed in MCF-7 cells. These observations are consistent with the cell context-dependent differences in hormonal regulation of Vegfr2; however, other factors must also be involved and this is currently being investigated.

Role of $E R \alpha$ and $E R \beta$ in activation of $E R / S p$. Initial studies investigated the role of $\mathrm{ER} \alpha$ and $\mathrm{ER} \beta$ in activating a GC-rich construct (pSP1) in breast and other cancer cell lines (Saville et al. 2000). The results showed that in these cancer cell lines transfected with $\mathrm{pSp}, \mathrm{ER} \alpha$, or $\mathrm{ER} \beta, \mathrm{E}_{2}$ activated $E R \alpha / S p$ but not ER $\beta /$ Sp. Subsequent domain swapping experiment with ER $\alpha$ and ER $\beta$ demonstrated that the N-terminal AF-1 domain of ER $\alpha$ was important for $\mathrm{E}_{2}$-dependent transactivation, whereas the corresponding A/B domain of ER $\beta$ fused to the N-terminal C-F domains of ER $\beta$ or ER $\alpha$ was inactive. These results are consistent with the lack of AF-1 activity in the A/B domain of ER $\beta$. Other studies on activation of $E R \alpha / S p$ versus $E R \beta / S p$ are variable and depend on promoter and cell context. ER $\alpha$ but not ER $\beta$ is involved in activation of PADI4 in HeLa cells (Dong et al. 2007); $\mathrm{E}_{2}$ activates GC-rich EGFR promoter constructs in HeLa cells transfected with ER $\alpha$ or ER $\beta$ (Salvatori et al. 2003). Both ER $\alpha$ and $\mathrm{ER} \beta$ were involved in hormone-dependent activation of GC-rich progesterone receptor promoter constructs; however, the induction response was dependent on cell context (Schultz et al. 2005). Kim et al. (2005) further investigated ER $\alpha-S P 1$ interactions using fluorescence resonance energy transfer (FRET). Although ER $\alpha$ and SP1 interactions in in vitro pulldown assays are ligand-independent, results of FRET studies show that in live MCF-7 cells, $\mathrm{E}_{2}$ clearly induces $\mathrm{ER} \alpha-\mathrm{Sp} 1$ interactions.

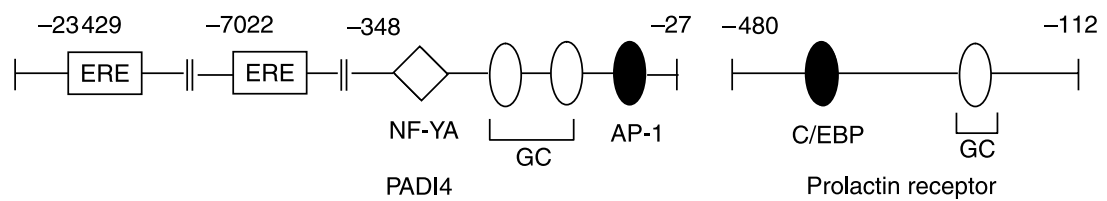

Figure 3 Multiple $E_{2}$-responsive elements. The PADI4 and prolactin receptor genes contain $\mathrm{E}_{2}$-responsive $\mathrm{GC}$-rich sites and other functional cis-element that contributed to $\mathrm{E}_{2^{-}}$ induced transactivation. 


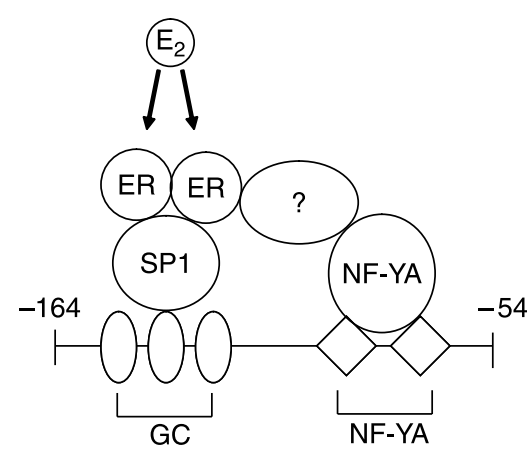

E2F1/MCF-7 cells

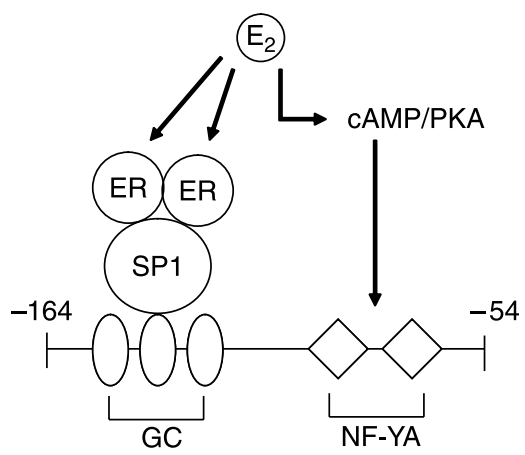

E2F1/ZR-75 cells

Figure 4 Different mechanisms of hormonal activation of E2f1 in MCF-7 cells and ZR-75 cells.

ER $\alpha$ activation of genes through SP1, SP3, and SP4. Most studies on $\mathrm{ER} \alpha / \mathrm{Sp}$-mediated transactivation have assumed that SP1 plays a major role in this response since this protein is overexpressed in cancer cell lines. However, since SP1, SP3, and SP4 proteins are expressed in breast cancer cells, we investigated the effects of individual Sp protein knockdown by RNA interference on the induction of Rara1, E2f1 and Cad gene expression by $\mathrm{E}_{2}$ in MCF-7 cells (Khan et al. 2007). All three genes contain GC-rich promoters; however, the role of individual Sp proteins on hormone responsiveness had not been determined. The results showed that knockdown of SP1, SP3, and SP4 significantly decreased the fold induction of RARA1, E2F1 and $\mathrm{CAD}$ by $\mathrm{E}_{2}$; however, loss of induction was greater in cells where SP3 or SP4 was decreased compared with decreased SP1. This demonstrates, at least for these three genes, that all three $\mathrm{Sp}$ proteins play role in $\mathrm{ER} \alpha / \mathrm{Sp}$ mediated transactivation in MCF-7 cells.

Ligand-dependent activation of ER $\alpha / S p$. Initial studies showed that in breast cancer cells transfected with pSP1 and wild-type $\mathrm{ER} \alpha$, both $\mathrm{E}_{2}$ and the antiestrogens, 4-hydroxytamoxifen (4-OHT) and ICI 182780 (fulvestrant), induced reporter gene (luciferase or chloramphenical acetyltransferase) activity (Porter et al. 1997, Saville et al. 2000, Kim et al. 2003). By contrast, $\mathrm{E}_{2}$ but not 4-OHT or ICI 182780 induced luciferase activity in breast cancer

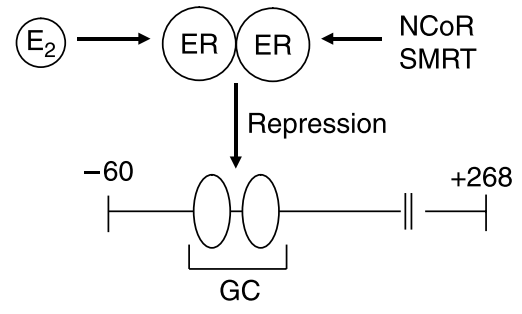

Vegfr2/MCF-7 cells cells transfected with GC-rich promoter-reporter constructs from several $\mathrm{E}_{2}$-responsive genes, demonstrating that promoter structure also influences the ER agonis$\mathrm{t} /$ antagonist activities of $\mathrm{E}_{2}$ and antiestrogens. The structure-dependent activation of $\mathrm{ER} \alpha / \mathrm{Sp}$ was also investigated in MCF-7 and MDA-MB-231 cells transfected with $\mathrm{pSP}_{3}$ and wild-type $\mathrm{ER} \alpha, \mathrm{ER} \alpha \Delta \mathrm{ZF} 1, \mathrm{ER} \alpha \Delta \mathrm{ZF} 2, \mathrm{ER} \alpha$ (1553), and ER $\alpha$ (1-537). These ER $\alpha$ mutants contained deletions of zinc finger 1 (amino acids 185-205), zinc finger 2 (amino acids 218-243), the $\mathrm{F}$ domain (amino acids 554-595), and the $\mathrm{F}$ domain plus amino acids in helix 12 of the E domain (amino acids 538-595) respectively (Fig. 6; Wu et al. 2008). The compounds used in this study included $\mathrm{E}_{2}$, diethylstilbestrol (DES), antiestrogens, the phytoestrogen resveratrol, and the xenoestrogens octylphenol (OP), nonylphenol (NP), endosulfan, kepone, 2,3,4,5-tetrachlorobiphenyl-4-ol (HO-PCB-Cl 4 ), bisphenol-A (BPA), and 2,2-bis-( $p$-hydroxyphenyl)-1,1,1-trichloroethane (HPTE). In MCF-7 cells, all compounds except resveratrol induced luciferase activity in cells transfected with wild-type $\mathrm{ER} \alpha$, whereas in MDA-MB-231 cells, even resveratrol was active. The concentrations of each compound were selected based on their maximal inducing response (with wild-type ER $\alpha$ ) that was not accompanied by cytotoxicity. $\mathrm{E}_{2}$ and the xenoestrogens activated wild-type ER $\alpha$ and ER $\alpha \Delta \mathrm{ZF} 1 / \mathrm{ER}$ $\alpha \Delta$ ZF2 in MCF-7 cells, whereas in MDA-MB-231 cells, NP

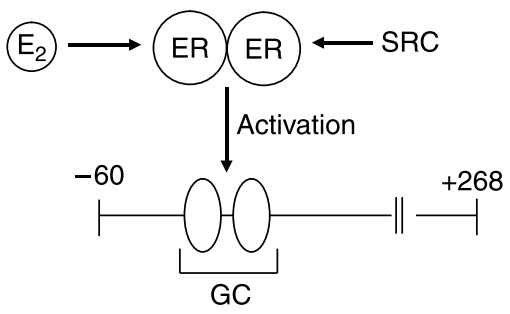

Vegfr2/ZR-75 cells

Figure 5 Mechanisms of $\mathrm{E}_{2}$-dependent downregulation and induction of Vegfr2 in MCF-7 and ZR-75 cells respectively. 
$\mathrm{ER} \alpha$ domain requirement

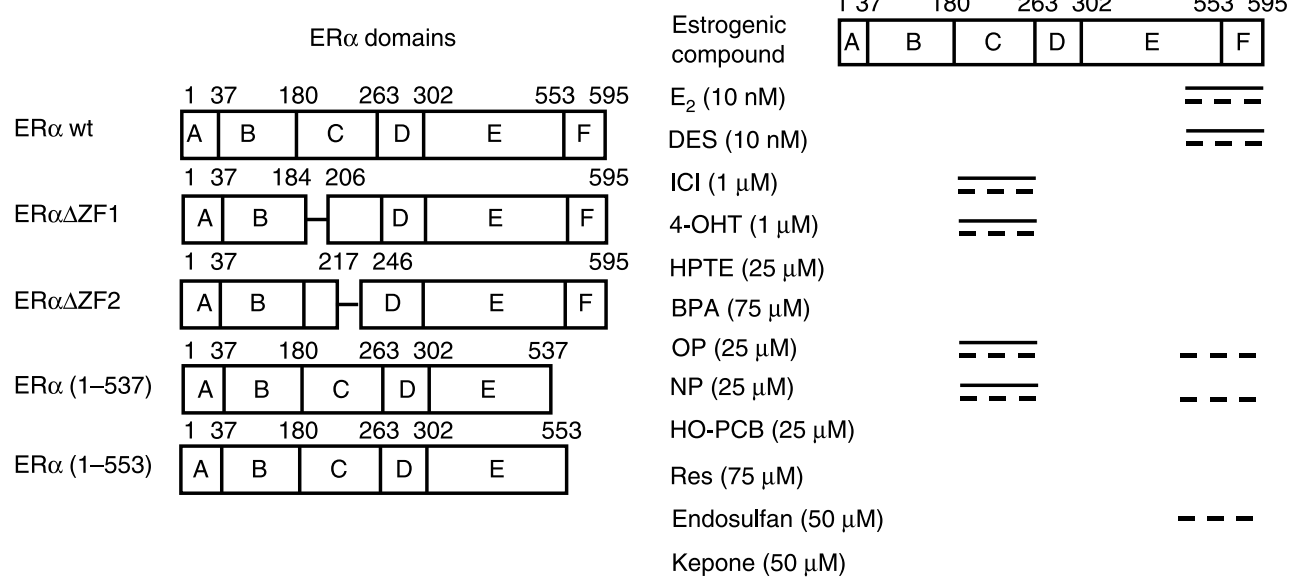

Figure 6 Wild-type and $E R$ variants and domains of ER required for transactivation by $E_{2}$ and structurally diverse estrogenic compounds in MCF-7 (-) and MDA-MB-231 (- - ) breast cancer cells.

and OP did not activate luciferase activity in cells transfected with $\mathrm{ER} \alpha \Delta \mathrm{ZF} 2$ and had minimal effects in cells transfected with ER $\alpha \Delta \mathrm{ZF1}$ (Fig. 6). Thus, with the exception of NP and OP, the xenoestrogens resembled $\mathrm{E}_{2}$ and DES but not 4-OHT or ICI 182780 . By contrast, 4-OHT and ICI 182780 but not $\mathrm{E}_{2}$ or DES induced transactivation in MCF-7 and MDA-MB-231 cells transfected with $\mathrm{ER} \alpha$ (1-537), a mutant form of $\mathrm{ER} \alpha$ that has lost part of helix 12 that interacts with coactivators. For this form of $\mathrm{ER} \alpha$, the xenoestrogens all induced luciferase activity and resembled the antiestrogenic drugs 4-OHT and ICI 182 780. These results demonstrate that the xenoestrogens can be both 'estrogen- and antiestrogen-like', depending on the expression of $\mathrm{ER} \alpha$ variants indicating that these compounds are selective ER modulators (SERMs).

RNA interference assays using small inhibitory RNAs for SP1, SP3, and SP4 also demonstrated structuredependent differences in activation of $\mathrm{ER} \alpha / \mathrm{SP} 1$, $\mathrm{ER} \alpha / \mathrm{SP} 3$, and $\mathrm{ER} \alpha / \mathrm{SP} 4$. 'Fold induction by estrogens $\left(\mathrm{E}_{2}\right.$ and DES), xenoestrogens, and antiestrogens exhibited three patterns that differentially relied upon $\mathrm{ER} \alpha / \mathrm{SP} 1, \mathrm{ER} \alpha / \mathrm{SP} 3, \mathrm{ER} \alpha / \mathrm{SP} 4$, or their combinations. For $\mathrm{E}_{2}$, HPTE, DES, and HO-PCB-Cl $\mathrm{H}_{4}, \mathrm{ER} \alpha / \mathrm{SP} 1>$ $\mathrm{ER} \alpha / \mathrm{SP} 4$, and $\mathrm{ER} \alpha / \mathrm{SP} 3$ had minimal to no effect on activation of $\mathrm{ER} \alpha / \mathrm{Sp}$ by these compounds. The pattern of $\mathrm{ER} \alpha / \mathrm{Sp}$ activation for BPA, endosulfan, NP, and 4-OHT was $\mathrm{ER} \alpha / \mathrm{SP} 1 \approx \mathrm{ER} \alpha / \mathrm{SP} 4$ with minimal contributions by ER $\alpha / \mathrm{SP} 3$. By contrast, both ER $\alpha / \mathrm{SP} 1$ and $\mathrm{ER} \alpha / \mathrm{SP} 3$ play roles in activation of $\mathrm{pSP}_{3}$ by ICI 182780 and kepone, but ER $\alpha / \mathrm{SP} 4$ tends to cause an inhibitory effect since iSP4 enhances the fold induction by these compounds' (Khan et al. 2007). These results illustrate the complexity of activation of $\mathrm{ER} \alpha / \mathrm{Sp}$ that depends on ligand structure, $\operatorname{ER} \alpha$ variant, and individual Sp proteins. Moreover, in this study, cells were transfected with the $\mathrm{pSP}_{3}$ construct that contains three tandem consensus GC-rich motifs and this pattern of induction will undoubtedly vary with different GC-rich promoter constructs.

\section{Ligand-dependent activation of ER/activating protein-1 (AP-1)}

\section{Introduction}

AP-1 is a transcription factor complex containing the protooncogenes jun, fos, and other family members, and this complex interacts with AP-1 sites in gene promoters to activate genes involved in cell growth, differentiation, and development. Early studies showed that fos and jun suppress ER-dependent transactivation from an ERE promoter (Doucas et al. 1991, Shemshedini et al. 1991, Tzukerman et al. 1991), and there are also reports that $\mathrm{E}_{2}$ induces expression of AP-1 transcription factors (Duan et al. 1998, 2001, 2002). AP-1 activity is also increased during the progression of MCF-7 cells to an antiestrogen-resistant phenotype, suggesting a role for this complex in $\mathrm{E}_{2}$-independent and more aggressive breast cancer cells (Dumont et al. 1996). In addition, there was also evidence that hormonal activation of insulin-like growth and ovalbumin involved AP-1 sites and that AP-1 may be important for $\mathrm{E}_{2}$-dependent activation or repression of the progesterone receptor, gonadotropin-releasing hormone receptor, matrix metalloproteinase-1 (MMP-1), prolactin, and pS2 genes (Van der Burg et al. 1990, Gaub et al. 1990, Philips et al. 1993, Savouret et al. 1994, Umayahara et al. 1994, Barkhem et al. 2002, Petz et al. 2002, Cheng et al. 2003, Duan et al. 2008, Scafonas et al. 2008). DeNardo et al. (2005) identified 20 new $\mathrm{E}_{2}$-induced genes that were 
AP-1 dependent, and microarrays also identified a subset of 32 ERE-independent differentially expressed genes in breast tumors (Glidewell-Kenney et al. 2005). These data confirm the importance of the non-classical genomic pathways for induction of genes by $\mathrm{E}_{2}$ and other estrogenic compounds. c-fos is induced by $\mathrm{E}_{2}$ through non-genomic and genomic pathways and the former pathway may also contribute to activation of ER/AP-1.

\section{Role of AP-1 proteins in hormonal modulation of gene expression}

\section{Estrogen/antiestrogen activation of ER/AP-1}

Webb et al. (1995) first reported the activation of an AP1 promoter-reporter construct derived from the human collagenase promoter. Antiestrogens such as ICI 182780 and 4-OHT and $\mathrm{E}_{2}$ activated the AP-1 construct in cancer cells (HeLa, NIH-3T3, HepG2, SHM, SY5Y, CEF, CV1, CHO, and F9) derived from several different tissues. In Ishikawa endometrial cancer cells, $\mathrm{E}_{2}$ and the antiestrogens activated AP-1; however, $\mathrm{E}_{2}$ but not 4-OHT or ICI 182780 activated the AP-1 promoter in ER-positive MCF-7 and ZR-75 cells. These results were interpreted as a mechanism by which antiestrogens such as tamoxifen can exhibit ER agonist activity through the non-classical ER/AP-1 pathway in which ER binds jun but not fos in pulldown assays where the N-terminal AF-1 region of $\mathrm{ER} \alpha$ is the major juninteracting site.

Subsequent studies compared the activation of ER $\alpha / \mathrm{AP}-1$ versus ER $\beta / \mathrm{AP}-1$ by $\mathrm{E}_{2}$ and selected SERMs that are used for breast cancer or other hormonal therapies (Paech et al. 1997). In HeLa cells, the antiestrogens raloxifene, 4-OHT and ICI 182780 but not $\mathrm{E}_{2}$ or DES activated ER $\beta / \mathrm{AP}-1$, and similar results were observed in Ishikawa, MCF-7, and ER-negative MDA-MB-453 breast cancer cells. By contrast, both estrogens and antiestrogens activated ER $\alpha / \mathrm{AP}-1$ in HeLa cells, demonstrating that cell context, ER subtype, and ligand structure were important for activation of ER/AP-1. Interestingly, these results clearly distinguish between ER/AP-1 versus ER/SP where $\mathrm{ER} \beta / \mathrm{Sp}$ is relatively inactive and wild-type $\mathrm{ER} \alpha / \mathrm{Sp}$ is activated by both estrogens and antiestrogens (Fig. 6).

\section{Effects of ER deletion mutants on activation of ER/AP-1}

Several studies have investigated the effects of wild-type and variant ER on activation of ER/AP-1 in different cell lines (Webb et al. 1995, 1999, Kushner et al. 2000, Jakacka et al. 2001, Weatherman \& Scanlan 2001, Bjornstrom \& Sjoberg 2002). It was initially reported that $\mathrm{E}_{2}$ but not antiestrogens activated HE11/AP-1 where HE11 is a DNA binding domain deletion mutant of ER $\alpha$ (Webb et al. 1995), and this was similar to results obtained for activation of HE11/Sp or the zinc finger deletion mutants ER $\alpha \Delta \mathrm{ZF} 1$ and ER $\alpha \Delta \mathrm{ZF} 2$ (Fig. 6). The effects of specific zinc finger mutants within the DNAbinding domain of $\mathrm{ER} \alpha$ have also been investigated (Jakacka et al. 2001, Bjornstrom \& Sjoberg 2002). The $\mathrm{ER} \alpha \mathrm{E} 207 \mathrm{G} / \mathrm{G} 208 \mathrm{~S}$ and E207A/G208A mutants do not bind DNA and, in ER-negative TSA cells transfected with these ER $\alpha$ mutants and an AP-1 reporter construct, ICI 182780 induced luciferase activity and $\mathrm{E}_{2}$ repressed activity (Jakacka et al. 2001). A more extensive study on a series of DNA-binding domain mutants of ER $\beta$ further demonstrated the complexity of ER $\alpha / A P-1-$ and ER $\beta / A P-1-m e d i a t e d$ transactivation in COS-7 and HE11 cells (Bjornstrom \& Sjoberg 2002). In HC11 cells transfected with wild-type ER $\beta$ and an AP-1 reporter construct, $\mathrm{E}_{2}$ repressed and the antiestrogens 4-OHT and ICI 182780 induced activity. However, in the same cell line transfected with $\operatorname{ER} \beta$ containing L206A, Y210A, and $\Delta 122-266$ (the entire DBD) mutant and several double mutants, $\mathrm{E}_{2}$ induced activity and the antiestrogens were inactive. Thus, subtle changes in the ER $\beta$ DBD completely reversed the ER agonist/antagonist activities of $\mathrm{E}_{2}$, 4-OHT, and ICI 182780 .

Elegant studies on ER $\alpha$ and ER $\beta$ deletion mutants and chimeric ERs with interchangeable domains have shown the importance of the C-terminal and $\mathrm{N}$-terminal AF-2 and AF-1 domains on ligand-dependent activation of ER/AP-1 (Webb et al. 1999, Weatherman \& Scanlan 2001). $\mathrm{E}_{2}$ induced transactivation of an AP-1 promoter containing only the LBD of $\mathrm{ER} \alpha$, whereas tamoxifen, raloxifene, and ICI 182780 were inactive. Subsequent studies on deletions of the AF-1 domain of $\mathrm{ER} \alpha$ showed that $\mathrm{E}_{2}$-induced transactivation was dependent on AF-1. The effects of tamoxifen were AF-1 independent but longer N-terminal deletions (129-178) resulted in loss of activity in HeLa cells. Interestingly, deletion of AF-1 from wild-type $\mathrm{ER} \alpha$ enhanced tamoxifen-induced transactivation and the response was similar to that observed in HeLa cells transfected with ER $\beta$, which does not contain AF-1-dependent activity. However, deletion of the N-terminal A/B domain of ER $\beta$ resulted in loss of tamoxifen-dependent activation of an AP-1 promoter in HeLa cells (Weatherman \& Scanlan 2001). Figure 7 compares the domain requirements for $\mathrm{E}_{2}$ and antiestrogens for activation of ER $\alpha / \mathrm{Sp}$ and $\mathrm{ER} \alpha / \mathrm{AP}-1$. Major differences were observed for $\mathrm{E}_{2}$ that required the AF-1 domain for activation of $\mathrm{ER} \alpha / \mathrm{Sp}$; activation of $\mathrm{ER} \alpha / \mathrm{AP}-1$ was also dependent on AF-1; however, loss of activity was observed after deletion of aa 127-178 in the N-terminal A/B domain.

\section{Structure-dependent activation of ER/AP-1}

The effects of structurally-diverse pharmacologic SERMs and xenoestrogens on activation of ER/AP-1 


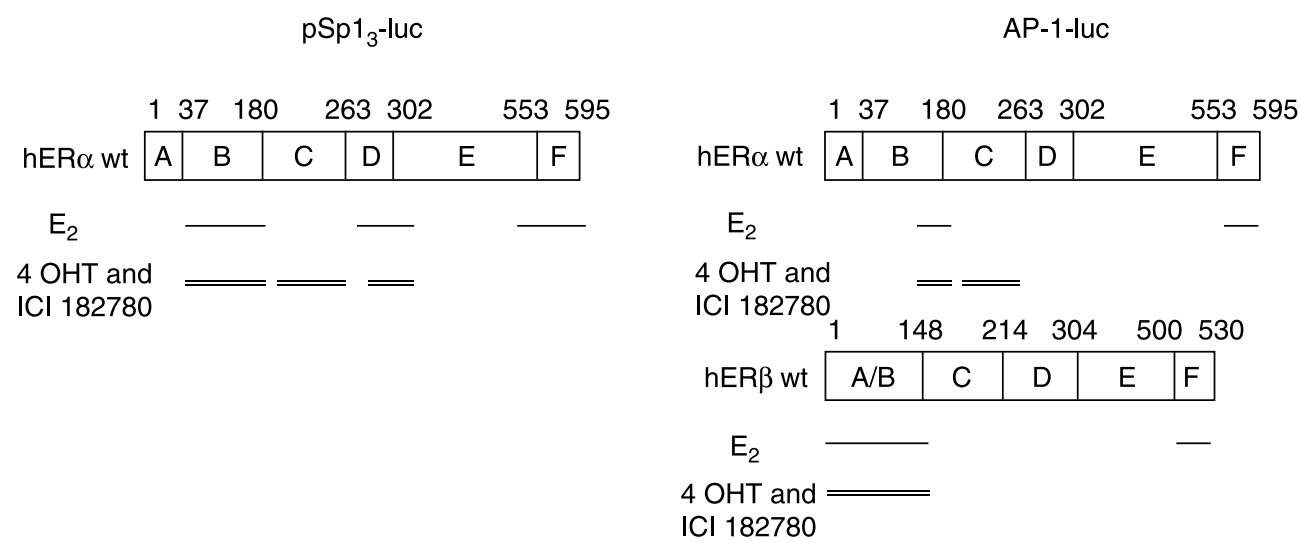

Figure 7 Domains of ER and ER required for ligand-dependent activation of ER/AP1 (i.e. deletion results in loss of activity) $(104,107)$ and comparisons with activation of ER/Sp.

have also been reported (Weatherman et al. 2001, Walters et al. 2002, Fujimoto et al. 2004). Differences in activation of ER $\alpha / \mathrm{AP}-1$ and ER $\beta / \mathrm{AP}-1$ were observed among several drugs being developed for endocrine therapy; however, $\mathrm{EC}_{50}$ values were generally lower for activation of ER $\beta / A P-1$ (Weatherman et al. 2001). The effects of several estrogenic compounds including xenoestrogens on activation of ERE-luc and AP-1-luc constructs cotransfected with ER $\alpha$ or $\operatorname{ER} \beta$ were investigated in NIH-3T3 cells (Fujimoto et al. 2004). Activation of ER $\alpha / \mathrm{AP}-1$ was observed in cells treated with most of the compounds including $\mathrm{E}_{2}$, 4-OHT, $17 \alpha$-estradiol, estriol, dienestrol, bisphenol A, $t$-methylbutylphenol, kepone, $p, p^{\prime}$-biphenol, genistein, o, $p^{\prime}$ DDD, zearalenol and $p, p^{\prime}$-DDE (but not $p, p^{\prime}$-DDT), whereas only 4-OHT activated ER $\beta / A P-1$. Thus, xenoestrogens primarily activate $\mathrm{ER} \alpha / \mathrm{AP}-1$ and some of the same compounds also activate ER $\alpha /$ Sp (Fig. 6).

\section{In vivo studies}

Jameson et al. initially developed a transgenic mouse model in which a mutant ER $\alpha$ (E207A/G208A; AA) knock-in mouse was generated to investigate promoter DNA-independent estrogenic activity of ER $\alpha$. The ER $\alpha$ mutant does not bind promoter DNA and therefore a comparison of the effects of $\mathrm{E}_{2}$ in wild-type and knockin mutant $\mathrm{ER} \alpha$ mice will provide important insights into the DNA (ERE)-independent effects of ER $\alpha$ that could include interactions with AP-1, Sp, and other transcription factors. The knock-in mice $\left(\mathrm{ER}^{+} / \mathrm{AA}\right)$ exhibited a gain of function since the females were infertile due to uterine defects and inovulation (Jakacka et al. 2002). These mice have now been bred on an ER $\alpha$ knockout $\left(\mathrm{ER}^{-/-}\right)$background to give $\mathrm{ER} \alpha^{-/ \mathrm{AA}}$ mice that can be used in comparative studies with $\mathrm{ER} \alpha^{+/+}, \mathrm{ER} \alpha^{-/-}$, and $\mathrm{ER} \alpha^{-/ \mathrm{AA}}$ mice to determine ERE-independent responses (O'Brien et al. 2006, Glidewell-Kenney et al. 2007, McDevitt et al. 2007, Syed et al. 2007). In the
$\mathrm{ER}^{-} / \mathrm{AA}$ mouse uterus, $\mathrm{E}_{2}$ and tamoxifen induced luminal epithelial cell proliferation but not other prototypical estrogen responses such as hyperemia and fluid retention (O'Brien et al. 2006). The contributions of ERE-independent versus ERE-dependent pathways were also investigated in the mouse reproductive axis. Estrogen-negative feedback control on luteneizing hormone secretion was primarily EREindependent, whereas positive feedback and ovulatory cyclicity were ERE-dependent processes (Glidewell-Kenney et al. 2007). Development of the male skeleton and sexual behavior in mice were primarily EREdependent, whereas secretion of testosterone was ERE-independent (McDevitt et al. 2007, Syed et al. 2007). These results clearly demonstrate an important role for ER/AP-1, ER/Sp, and other DNA-independent estrogenic pathways in mice. However, it is also possible that some of the ERE-dependent/-independent responses may be due to non-genomic pathways and their relative contributions of genomic versus nongenomic $\mathrm{E}_{2}$-dependent responses in mice and humans requires further research and development of appropriate animal models.

\section{Summary}

Ligand-dependent activation of ER is highly complex and dependent on ligand structure, ER subtype and intracellular location, promoter, and cell context. The non-classical genomic ER/Sp and ER/AP-1 regulate a large number of genes through both distinct and overlapping pathways. Studies on the identification of genome-wide ER binding sites have confirmed the association of this hormone receptor with other nuclear factors and binding motifs including GC-rich and AP-1 sites (Carroll \& Brown 2006, Carroll et al. 2006, Vega et al. 2006, Kininis et al. 2007, Lin et al. 2007, Gao et al. 2008). It has also been reported that many 
$\mathrm{E}_{2}$-responsive genes are regulated by interactions of ER with cis-elements that are distal to their corresponding transcription start sites. Thus, the molecular biology of $\mathrm{E}_{2}$-dependent activation of ER/Sp and ER/AP-1 and their associated genes may also include contributions of distal binding sites that have not yet been characterized. The ligand structure- and ER subtype-dependent patterns of activation of ER/Sp and ER/AP-1 are different (Figs 6 and 7), and this may be due, in part, to the relative expression of cofactors required for $\mathrm{ER} / \mathrm{Sp}$ and ER/AP-1-mediated transactivation. Although coactivator/cofactor requirements for activation of classical ERE promoters have been exhaustively investigated, only a few reports have determined functional coactivator-ER/Sp and ER-AP-1 interactions. Steroid receptor coactivator 2 (or GRIP1) enhances ER $\alpha / \mathrm{AP}-m e d i a t e d$ transcription, and this response requires LXXLL boxes in the coactivator that facilitates interactions with the AF2 domain of $\mathrm{ER} \alpha$ (Webb et al. 1999). This is consistent with similar pathways for coactivation of ER $\alpha$ (EREdependent) and ER $\alpha / \mathrm{AP}-1$ (Webb et al. 1999). Receptor-interacting protein 140 (RIP140) repressed $\mathrm{E}_{2}$-induced activation of $\mathrm{ER} \alpha / \mathrm{AP}-1$ by reversing the effects of SRC2 (Teyssier et al. 2003). By contrast, studies with the vitamin D-interacting protein 150 (DRIP150) coactivator demonstrated that DRIP150 coactivation of $\mathrm{ER} \alpha / \mathrm{Sp}$ was LXXLL-box-independent and required a novel helical region in DRIP150 (Lee \& Safe 2007). Cell context-dependent induction and repression of Vegfr2 in ZR-75 and MCF-7 cells respectively is associated with the same GC-rich promoter sequences but there were differences in recruitment of coactivators (induction) and corepressors, such as NCoR and SMRT (Higgins et al. 2006, 2008). Further studies are required on the mechanisms and proteins associated with coactivation and repression of $\mathrm{ER} / \mathrm{Sp}$ and $\mathrm{ER} / \mathrm{AP}-1$, since in vivo studies demonstrate that these ERE-independent pathways play an important role in mediating the effects of estrogens, pharmacologic, and other synthetic or naturally occurring SERMs.

\section{Declaration of interest}

The authors declare that there is no conflict of interest that could be perceived as prejudicing the impartiality of the research reported.

\section{Funding}

This research was funded by a grant from the National Institutes of Health (ES04917).

\section{Acknowledgements}

Assistance from Texas AgriLife is gratefully acknowledged.

\section{References}

Ammendola R, Mesuraca M, Russo T \& Cimino F 1992 Sp1 DNA binding efficiency is highly reduced in nuclear extracts from aged rat tissues. Journal of Biological Chemistry 267 17944-17948.

Augereau P, Miralles F, Cavailles V, Gaudelet C, Parker M \& Rochefort H 1994 Characterization of the proximal estrogen-responsive element of human cathepsin D gene. Molecular Endocrinology 8 693-703.

Bardin A, Moll F, Margueron R, Delfour C, Chu ML, Maudelonde T, Cavailles V \& Pujol P 2005 Transcriptional and posttranscriptional regulation of fibulin-1 by estrogens leads to differential induction of messenger ribonucleic acid variants in ovarian and breast cancer cells. Endocrinology 146 760-768.

Barkhem T, Haldosen LA, Gustafsson JA \& Nilsson S 2002 pS2 Gene expression in HepG2 cells: complex regulation through crosstalk between the estrogen receptor $\alpha$, an estrogen-responsive element, and the activator protein 1 response element. Molecular Pharmacology 61 1273-1283.

Batistuzzo de Medeiros SR, Krey G, Hihi AK \& Wahli W 1997 Functional interactions between the estrogen receptor and the transcription activator Spl regulate the estrogen-dependent transcriptional activity of the vitellogenin $\mathrm{A} 1$ io promoter. Journal of Biological Chemistry 272 18250-18260.

Bjornstrom L \& Sjoberg M 2002 Mutations in the estrogen receptor DNA-binding domain discriminate between the classical mechanism of action and cross-talk with Stat5b and activating protein 1 (AP-1). Journal of Biological Chemistry 277 48479-48483.

Black AR, Black JD \& Azizkhan-Clifford J 2001 Sp1 and Krüppel-like factor family of transcription factors in cell growth regulation and cancer. Journal of Cellular Physiology 188 143-160.

Boggess JF, Zhou C, Bae-Jump VL, Gehrig PA \& Whang YE 2006 Estrogen-receptor-dependent regulation of telomerase activity in human endometrial cancer cell lines. Gynecologic Oncology 103 $417-424$.

Bouwman P \& Philipsen S 2002 Regulation of the activity of Sp1related transcription factors. Molecular and Cellular Endocrinology 195 27-38.

Briggs MR, Kadonaga JT, Bell SP \& Tjian R 1986 Purification and biochemical characterization of the promoter- specific transcription factor, Sp1. Science 234 47-52.

Van der Burg B, De Groot RP, Isbrücker L, Kruijer W \& De Laat SW 1990 Stimulation of TPA-responsive element activity by a cooperative action of insulin and estrogen in human breast cancer cells. Molecular Endocrinology 4 1720-1726.

Byrne IM, Flanagan L, Tenniswood MP \& Welsh J 2000 Identification of a hormone-responsive promoter immediately upstream of exon 1c in the human vitamin D receptor gene. Endocrinology 141 2829-2836.

Carroll JS \& Brown M 2006 Estrogen receptor target gene: an evolving concept. Molecular Endocrinology 20 1707-1714.

Carroll JS, Meyer CA, Song J, Li W, Geistlinger TR, Eeckhoute J, Brodsky AS, Keeton EK, Fertuck KC, Hall GF et al. 2006 Genomewide analysis of estrogen receptor binding sites. Nature Genetics 38 $1289-1297$.

Castro-Rivera E, Samudio I \& Safe S 2001 Estrogen regulation of cyclin D1 gene expression in ZR-75 breast cancer cells involves multiple enhancer elements. Journal of Biological Chemistry 276 30853-30861.

Cavailles V, Augereau P \& Rochefort H 1993 Cathepsin D gene is controlled by a mixed promoter, and estrogens stimulate only TATA-dependent transcription. PNAS 90 203-207.

Cheng CK, Chow BK \& Leung PC 2003 An activator protein 1-like motif mediates $17 \beta$-estradiol repression of gonadotropin-releasing hormone receptor promoter via an estrogen receptor $\alpha$-dependent mechanism in ovarian and breast cancer cells. Molecular Endocrinology 17 2613-2629. 
Chiefari E, Brunetti A, Arturi F, Bidart JM, Russo D, Schlumberger M \& Filetti S 2002 Increased expression of AP2 and Sp1 transcription factors in human thyroid tumors: a role in NIS expression regulation? BMC Cancer 235.

Curtin D, Jenkins S, Farmer N, Anderson AC, Haisenleder DJ, Rissman E, Wilson EM \& Shupnik MA 2001 Androgen suppression of GnRHstimulated rat LH $\beta$ gene transcription occurs through Sp1 sites in the distal GnRH-responsive promoter region. Molecular Endocrinology 15 1906-1917.

DeNardo DG, Kim HT, Hilsenbeck S, Cuba V, Tsimelzon A \& Brown PH 2005 Global gene expression analysis of estrogen receptor transcription factor cross talk in breast cancer: identification of estrogen-induced/activator protein-1-dependent genes. Molecular Endocrinology 19 362-378.

Dong L, Wang W, Wang F, Stoner M, Reed JC, Harigai M, Kladde M, Vyhlidal C \& Safe S 1999 Mechanisms of transcriptional activation of bcl-2 gene expression by $17 \beta$-estradiol in breast cancer cells. Journal of Biological Chemistry 174 32099-32107.

Dong J, Tsai-Morris CH \& Dufau ML 2006 A novel estradiol/estrogen receptor $\alpha$-dependent transcriptional mechanism controls expression of the human prolactin receptor. Journal of Biological Chemistry 281 18825-18836.

Dong S, Zhang Z \& Takahara H 2007 Estrogen-enhanced peptidylarginine deiminase type IV gene (PADI4) expression in MCF-7 cells is mediated by estrogen receptor- $\alpha$-promoted transfactors activator protein-1, nuclear factor-Y, and Sp1. Molecular Endocrinology 21 $1617-1629$.

Doucas V, Spyrou G \& Yaniv M 1991 Unregulated expression of c-Jun and c-Fos proteins but not Jun D inhibits oestrogen receptor activity in human breast cancer-derived cells. EMBO Journal 10 2237-2245.

Duan R, Porter W \& Safe S 1998 Estrogen-induced c-fos protooncogene expression in MCF-7 human breast cancer cells: role of estrogen receptor Sp1 complex formation. Endocrinology 139 1981-1990.

Duan R, Xie W, Burghardt R \& Safe S 2001 Estrogen receptormediated activation of the serum response element in MCF-7 cells through MAPK-dependent phosphorylation of Elk-1. Journal of Biological Chemistry 276 11590-11598.

Duan R, Xie W, Li X, McDougal A \& Safe S 2002 Estrogen regulation of c-fos gene expression through phosphatidylinositol-3-kinasedependent activation of serum response factor in MCF-7 breast cancer cells. Biochemical and Biophysical Research Communications 294 384-394.

Duan R, Ginsburg E \& Vonderhaar BK 2008 Estrogen stimulates transcription from the human prolactin distal promoter through AP1 and estrogen responsive elements in T47D human breast cancer cells. Molecular and Cellular Endocrinology 281 9-18.

Dubik D \& Shiu RPC 1992 Mechanism of estrogen activation of c-myc oncogene expression. Oncogene 7 1587-1594.

Dumont JA, Bitonti AJ, Wallace CD, Baumann RJ, Cashman EA \& Cross-Doersen DE 1996 Progression of MCF-7 breast cancer cells to antiestrogen-resistant phenotype is accompanied by elevated levels of AP-1 DNA-binding activity. Cell Growth and Differentiation 7 351-359.

Dynan WS \& Tjian R 1983 The promoter-specific transcription factor Sp1 binds to upstream sequences in the SV40 early promoter. Cell 35 79-87.

Dynan WS \& Tjian R 1985 Control of eukaryotic messenger RNA synthesis by sequence-specific DNA-binding proteins. Nature 316 774-778.

Fleming JG, Spencer TE, Safe SH \& Bazer FW 2006 Estrogen regulates transcription of the ovine oxytocin receptor gene through GC-rich SP1 promoter elements. Endocrinology 147 899-911.

Fujimoto N, Honda H \& Kitamura S 2004 Effects of environmental estrogenic chemicals on AP1 mediated transcription with estrogen receptors $\alpha$ and $\beta$. Journal of Steroid Biochemistry and Molecular Biology 88 53-59.
Fujita N, Kajita M, Taysavang P \& Wade PA 2004 Hormonal regulation of metastasis-associated protein 3 transcription in breast cancer cells. Molecular Endocrinology 18 2937-2949.

Gao H, Falt S, Sandelin A, Gustafsson JA \& hlman-Wright K 2008 Genome-wide identification of estrogen receptor $\alpha$-binding sites in mouse liver. Molecular Endocrinology 22 10-22.

Gaub M-P, Bellard M, Scheuer I, Chambon P \& Sassone-Corsi P 1990 Activation of the ovalbumin gene by the estrogen receptor involves the Fos-Jun complex. Cell 63 1267-1276.

Glidewell-Kenney C, Weiss J, Lee EJ, Pillai S, Ishikawa T, Ariazi EA \& Jameson JL 2005 ERE-independent ER $\alpha$ target genes differentially expressed in human breast tumors. Molecular and Cellular Endocrinology 245 53-59.

Glidewell-Kenney C, Hurley LA, Pfaff L, Weiss J, Levine JE \& Jameson JL 2007 Nonclassical estrogen receptor $\alpha$ signaling mediates negative feedback in the female mouse reproductive axis. PNAS 104 8173-8177.

Gollner H, Bouwman P, Mangold M, Karis A, Braun H, Rohner I, Del Rey A, Besedovsky HO, Meinhardt A, van den Broek M et al. 2001 a Complex phenotype of mice homozygous for a null mutation in the Sp4 transcription factor gene. Genes to Cells 6 689-697.

Gollner H, Dani C, Phillips B, Philipsen S \& Suske G $2001 b$ Impaired ossification in mice lacking the transcription factor Sp3. Mechanisms of Development 106 77-83.

Higgins KJ, Liu S, Abdelrahim M, Yoon K, Vanderlaag K, Porter W, Metz RP \& Safe S 2006 Vascular endothelial growth factor receptor2 expression is induced by $17 \beta$-estradiol in ZR-75 breast cancer cells by estrogen receptor $\alpha /$ Sp proteins. Endocrinology 147 3285-3295.

Higgins KJ, Liu S, Abdelrahim M, Vanderlaag K, Liu X, Porter W, Metz R \& Safe S 2008 Vascular endothelial growth factor receptor-2 expression is downregulated by $17 \beta$-estradiol in MCF-7 breast cancer cells by estrogen receptor $\alpha /$ Sp proteins. Molecular Endocrinology 22 388-402.

Hosoi Y, Watanabe T, Nakagawa K, Matsumoto Y, Enomoto A, Morita A, Nagawa H \& Suzuki N 2004 Up-regulation of DNA-dependent protein kinase activity and Sp1 in colorectal cancer. International Journal of Oncology 25 461-468.

Husmann M, Dragneva Y, Romahn E \& Jehnichen P 2000 Nuclear receptors modulate the interaction of Sp1 and GC-rich DNA via ternary complex formation. Biochemical Journal 352 763-772.

Jacobson D, Pribnow D, Herson PS, Maylie J \& Adelman JP 2003 Determinants contributing to estrogen-regulated expression of SK3. Biochemical and Biophysical Research Communications 303 660-668.

Jakacka M, Ito M, Weiss J, Chien P-Y, Gehm BD \& Jameson JL 2001 Estrogen receptor binding to DNA is not required for its activity through the nonclassical AP1 pathway. Journal of Biological Chemistry 276 13615-13621.

Jakacka M, Ito M, Martinson F, Ishikawa T, Lee EJ \& Jameson JL 2002 An estrogen receptor (ER) $\alpha$ deoxyribonucleic acid-binding domain knock-in mutation provides evidence for nonclassical ER pathway signaling in vivo. Molecular Endocrinology 16 2188-2201.

Kanai M, Wei D, Li Q, Jia Z, Ajani J, Le X, Yao J \& Xie K 2006 Loss of Krüppel-like factor 4 expression contributes to $\mathrm{Spl}$ overexpression and human gastric cancer development and progression. Clinical Cancer Research 12 6395-6402.

Kelley KM, Rowan BG \& Ratnam M 2003 Modulation of the folate receptor $\alpha$ gene by the estrogen receptor: mechanism and implications in tumor targeting. Cancer Research 63 2820-2828.

Khan S, Abdelrahim M, Samudio I \& Safe S 2003 Estrogen receptor/Spl complexes are required for induction of cad gene expression by $17 \beta$-estradiol in breast cancer cells. Endocrinology 144 2325-2335.

Khan S, Wu F, Liu S, Wu Q \& Safe S 2007 Role of specificity protein (Sp) transcription factors in estrogen-induced gene expression in MCF-7 breast cancer cells. Journal of Molecular Endocrinology 39 289-304. 
Kim K, Nguyen T, Saville B \& Safe S 2003 Domains of estrogen receptor $\alpha(\mathrm{ER} \alpha)$ required for $\mathrm{ER} \alpha / \mathrm{Sp} 1-$ mediated activation of GC-rich promoters by estrogens and antiestrogens in breast cancer cells. Molecular Endocrinology 17 804-817.

Kim K, Barhoumi R, Burghardt R \& Safe S 2005 Analysis of estrogen receptor $\alpha-\mathrm{Sp} 1$ interactions in breast cancer cells by fluorescence resonance energy transfer. Molecular Endocrinology 19 843-854.

Kininis M, Chen BS, Diehl AG, Isaacs GD, Zhang T, Siepel AC, Clark AG \& Kraus WL 2007 Genomic analyses of transcription factor binding, histone acetylation, and gene expression reveal mechanistically distinct classes of estrogen-regulated promoters. Molecular and Cellular Biology 27 5090-5104.

Krishnan V, Wang X \& Safe S 1994 Estrogen receptor-Spl complexes mediate estrogen-induced cathepsin D gene expression in MCF-7 human breast cancer cells. Journal of Biological Chemistry 269 15912-15917.

Krishnan V, Porter W, Santostefano M, Wang X \& Safe S 1995 Molecular mechanism of inhibition of estrogen-induced cathepsin D gene expression by 2,3,7,8-tetrachlorodibenzo- $p$-dioxin (TCDD) in MCF-7 cells. Molecular and Cellular Biology 15 6710-6719.

Kundu P, Alioua A, Stefani E \& Toro L 2007 Regulation of mouse Slo gene expression: multiple promoters, transcription start sites, and genomic action of estrogen. Journal of Biological Chemistry 282 27478-27492.

Kushner PJ, Agard DA, Greene GL, Scanlan TS, Shiau AK, Uht RM \& Webb P 2000 Estrogen receptor pathways to AP-1. Journal of Steroid Biochemistry and Molecular Biology 74 311-317.

Lee J \& Safe S 2007 Coactivation of estrogen receptor $\alpha(E R \alpha) / S p 1$ by vitamin D receptor interacting protein 150 (DRIP150). Archives of Biochemistry and Biophysics 461 200-210.

Li D, Mitchell D, Luo J, Yi Z, Cho SG, Guo J, Li X, Ning G, Wu X \& Liu M 2007 Estrogen regulates KiSS1 gene expression through estrogen receptor $\alpha$ and SP protein complexes. Endocrinology 148 4821-4828.

Lin CY, Vega VB, Thomsen JS, Zhang T, Kong SL, Xie M, Chiu KP, Lipovich L, Barnett DH, Stossi F et al. 2007 Whole-genome cartography of estrogen receptor $\alpha$ binding sites. PLoS Genetics 3 e87.

Liu D, Zhang Z, Gladwell W \& Teng CT 2003 Estrogen stimulates estrogen-related receptor $\alpha$ gene expression through conserved hormone response elements. Endocrinology 144 4894-4904.

Lou Z, O'Reilly S, Liang H, Maher VM, Sleight SD \& Mccormick JJ 2005 Down-regulation of overexpressed Spl protein in human fibrosarcoma cell lines inhibits tumor formation. Cancer Research 65 $1007-1017$.

Lu S, Jenster G \& Epner DE 2000 Androgen induction of cyclindependent kinase inhibitor p21 gene: role of androgen receptor and transcription factor Spl complex. Molecular Endocrinology 14 753-760.

Maor S, Mayer D, Yarden RI, Lee AV, Sarfstein R, Werner H \& Papa MZ 2006 Estrogen receptor regulates insulin-like growth factor-I receptor gene expression in breast tumor cells: involvement of transcription factor Sp1. Journal of Endocrinology 191 605-612.

Marin M, Karis A, Visser P, Grosveld F \& Phillipsen S 1997 Transcription factor Sp1 is essential for early embryonic development but dispensable for cell growth and differentiation. Cell $\mathbf{8 9}$ $619-628$

Martin R, Taylor MB, Krikun G, Lockwood C, Akbas GE \& Taylor HS 2007 Differential cell-specific modulation of HOXA10 by estrogen and specificity protein 1 response elements. Journal of Clinical Endocrinology and Metabolism 92 1920-1926.

Martini PG \& Katzenellenbogen BS 2001 Regulation of prothymosin $\alpha$ gene expression by estrogen in estrogen receptor-containing breast cancer cells via upstream half-palindromic estrogen response element motifs. Endocrinology 142 3493-3501.

McDevitt MA, Glidewell-Kenney C, Weiss J, Chambon P, Jameson JL \& Levine JE 2007 Estrogen response element-independent estrogen receptor (ER)- $\alpha$ signaling does not rescue sexual behavior but restores normal testosterone secretion in male ER $\alpha$ knockout mice. Endocrinology 148 5288-5294.

Mertens-Talcott SU, Chintharlapalli S, Li X \& Safe S 2007 The oncogenic microRNA-27a targets genes that regulate specificity protein $(\mathrm{Sp})$ transcription factors and the G2-M checkpoint in MDA-MB-231 breast cancer cells. Cancer Research 67 11001-11011.

Moorefield KS, Fry SJ \& Horowitz JM 2004 Sp2 DNA binding activity and trans-activation are negatively regulated in mammalian cells. Journal of Biological Chemistry 279 13911-13924.

Ngwenya S \& Safe S 2003 Cell context-dependent differences in the induction of E2F-1 gene expression by $17 \beta$-estradiol in MCF-7 and ZR-75 cells. Endocrinology 144 1675-1685.

O'Brien JE, Peterson TJ, Tong MH, Lee EJ, Pfaff LE, Hewitt SC, Korach KS, Weiss J \& Jameson JL 2006 Estrogen-induced proliferation of uterine epithelial cells is independent of estrogen receptor $\alpha$ binding to classical estrogen response elements. Journal of Biological Chemistry 281 26683-26692.

Oh JE, Han JA \& Hwang ES 2007 Downregulation of transcription factor, Sp1, during cellular senescence. Biochemical and Biophysical Research Communications 353 86-91.

Owen GI, Richer JK, Tung L, Takimoto G \& Horwitz KB 1998 Progesterone regulates transcription of the p21WAF1 cyclindependent kinase inhibitor gene through $\mathrm{Sp} 1$ and $\mathrm{CBP} / \mathrm{p} 300$. Journal of Biological Chemistry 273 10696-10701.

Paech K, Webb P, Kuiper GG, Nilsson S, Gustafsson J, Kushner PJ \& Scanlan TS 1997 Differential ligand activation of estrogen receptors $\mathrm{ER} \alpha$ and ER $\beta$ at AP1 sites. Science 277 1508-1510.

Petz LN \& Nardulli AM 2000 Sp1 binding sites and an estrogen response element half-site are involved in regulation of the human progesterone receptor A promoter. Molecular Endocrinology 14 972-985.

Petz LN, Ziegler YS, Loven MA \& Nardulli AM 2002 Estrogen receptor $\alpha$ and activating protein- 1 mediate estrogen responsiveness of the progesterone receptor gene in MCF-7 breast cancer cells. Endocrinology 143 4583-4591.

Philips A, Chalbos D \& Rochefort H 1993 Estradiol increases and antiestrogens antagonize the growth factor-induced activator protein-1 activity in MCF-7 breast cancer cells without affecting c-fos and c-jun synthesis. Journal of Biological Chemistry 268 14103-14108.

Philipsen S \& Suske G 1999 A tale of three fingers: the family of mammalian Sp/XKLF transcription factors. Nucleic Acids Research 27 2991-3000.

Porter W, Wang F, Wang W, Duan R \& Safe S 1996 Role of estrogen receptor/Sp1 complexes in estrogen-induced heat shock protein 27 gene expression. Molecular Endocrinology 10 1371-1378.

Porter W, Saville B, Hoivik D \& Safe S 1997 Functional synergy between the transcription factor Sp1 and the estrogen receptor. Molecular Endocrinology 11 1569-1580.

Qin C, Singh P \& Safe S 1999 Transcriptional activation of insulin-like growth factor binding protein 4 by $17 \beta$-estradiol in MCF-7 cells: role of estrogen receptor-Sp1 complexes. Endocrinology 140 2501-2508.

Safe S 2001 Transcriptional activation of genes by $17 \beta$-estradiol through estrogen receptor-Sp1 interactions. Vitamins and Hormones 62 231-252.

Safe S \& Abdelrahim M 2005 Sp transcription factor family and its role in cancer. European Journal of Cancer 41 2438-2448.

Safe S \& Kim K 2004 Nuclear receptor-mediated transactivation through interaction with Sp proteins. Progress in Nucleic Acid Research and Molecular Biology 77 1-36.

Salvatori L, Ravenna L, Felli MP, Cardillo MR, Russo MA, Frati L, Gulino A \& Petrangeli E 2000 Identification of an estrogenmediated deoxyribonucleic acid-binding independent transactivation pathway on the epidermal growth factor receptor gene promoter. Endocrinology 141 2266-2274. 
Salvatori L, Pallante P, Ravenna L, Chinzari P, Frati L, Russo MA \& Petrangeli E 2003 Oestrogens and selective oestrogen receptor (ER) modulators regulate EGF receptor gene expression through human ER $\alpha$ and $\beta$ subtypes via an Sp1 site. Oncogene 22 4875-4881.

Samudio I, Vyhlidal C, Wang F, Stoner M, Chen I, Kladde M, Barhoumi R, Burghardt R \& Safe S 2001 Transcriptional activation of DNA polymerase $\alpha$ gene expression in MCF-7 cells by $17 \beta$-estradiol. Endocrinology 142 1000-1008.

Saville B, Wormke M, Wang F, Nguyen T, Enmark E, Kuiper G, Gustafsson J-A \& Safe S 2000 Ligand-, cell- and estrogen receptor subtype $(\alpha / \beta)$-dependent activation at GC-rich $(\mathrm{Spl})$ promoter elements. Journal of Biological Chemistry 275 5379-5387.

Savouret JF, Rauch M, Redeuilh G, Sar S, Chauchereau A, Woodruff K, Parker MG \& Milgrom E 1994 Interplay between estrogens, progestins, retinioic acid and AP-1 on a single regulatory site in the progesterone receptor gene. Journal of Biological Chemistry $\mathbf{2 6 9}$ $28955-28962$.

Scafonas A, Reszka AA, Kimmel DB, Hou XS, Su Q, Birzin ET, Kim S, Chen HY, Tan Q, Roher SP et al. 2008 Agonist-like SERM effects on $\mathrm{ER} \alpha$-mediated repression of MMP1 promoter activity predict in vivo effects on bone and uterus. Journal of Steroid Biochemistry and Molecular Biology 110 197-206.

Scholz A, Truss M \& Beato M 1998 Hormone-induced recruitment of Sp1 mediates estrogen activation of the rabbit uteroglobin gene in endometrial epithelium. Journal of Biological Chemistry 273 $4360-4366$.

Schultz JR, Petz LN \& Nardulli AM 2003 Estrogen receptor $\alpha$ and Sp1 regulate progesterone receptor gene expression. Molecular and Cellular Endocrinology 201 165-175.

Schultz JR, Petz LN \& Nardulli AM 2005 Cell- and ligand-specific regulation of promoters containing activator protein-1 and Sp1 sites by estrogen receptors $\alpha$ and $\beta$. Journal of Biological Chemistry $\mathbf{2 8 0}$ $347-354$.

Shemshedini L, Knauthe R, Sassone-Corsi P, Pornon A \& Gronemeyer H 1991 Cell-specific inhibitory and stimulatory effects of Fos and Jun on transcription activation by nuclear receptors. EMBO Journal 10 3839-3849.

Shi Q, Le X, Abbruzzese JL, Peng Z, Qian CN, Tang H, Xiong Q, Wang B, Li XC \& Xie K 2001 Constitutive Sp1 activity is essential for differential constitutive expression of vascular endothelial growth factor in human pancreatic adenocarcinoma. Cancer Research 61 4143-4154.

Simmen RCM, Chung TE, Imataka H, Michel FJ, Badinga L \& Simmen FA 1999 Trans-activation functions of the Sp-related nuclear factor, basic transcription element-binding protein, and progesterone receptor in endometrial epithelial cells. Endocrinology 140 2517-2525.

Stoner M, Wang F, Wormke M, Nguyen T, Samudio I, Vyhlidal C, Marme D, Finkenzeller G \& Safe S 2000 Inhibition of vascular endothelial growth factor expression in HEC1A endometrial cancer cells through interactions of estrogen receptor $\alpha$ and Sp3 proteins. Journal of Biological Chemistry 275 22769-22779.

Stoner M, Wormke M, Saville B, Samudio I, Qin C, Abdelrahim M \& Safe S 2004 Estrogen regulation of vascular endothelial growth factor gene expression in ZR-75 breast cancer cells through interaction of estrogen receptor $\alpha$ and Sp proteins. Oncogene $\mathbf{2 3}$ 1052-1063.

Sun G, Porter W \& Safe S 1998 Estrogen-induced retinoic acid receptor $\alpha 1$ gene expression: role of estrogen receptor-Sp1 complex. Molecular Endocrinology 12 882-890.

Sun JM, Spencer VA, Li L, Yu CH, Yu J \& Davie JR 2005 Estrogen regulation of trefoil factor 1 expression by estrogen receptor $\alpha$ and Sp proteins. Experimental Cell Research 302 96-107.

Supp DM, Witte DP, Branford WW, Smith EP \& Potter SS 1996 Sp4, a member of the Spl-family of zinc finger transcription factors, is required for normal murine growth, viability, and male fertility. Developmental Biology 176 284-299.
Suske G, Bruford E \& Philipsen S 2005 Mammalian SP/KLF transcription factors: bring in the family. Genomics 85 551-556.

Syed FA, Fraser DG, Spelsberg TC, Rosen CJ, Krust A, Chambon P, Jameson JL \& Khosla S 2007 Effects of loss of classical estrogen response element signaling on bone in male mice. Endocrinology 148 1902-1910.

Tanaka N, Yonekura H, Yamagishi S, Fujimori H, Yamamoto Y \& Yamamoto H 2000 The receptor for advanced glycation end products is induced by the glycation products themselves and tumor necrosis factor- $\alpha$ through nuclear factor- $\kappa \mathrm{B}$, and by $17 \beta-$ estradiol through Sp-1 in human vascular endothelial cells. Journal of Biological Chemistry 275 25781-25790.

Teyssier C, Belguise K, Galtier F, Cavailles V \& Chalbos D 2003 Receptorinteracting protein 140 binds c-Jun and inhibits estradiol-induced activator protein-1 activity by reversing glucocorticoid receptorinteracting protein 1 effect. Molecular Endocrinology 17 287-299.

Tzukerman M, Zhang X-K \& Pfahl M 1991 Inhibition of estrogen receptor activity by the tumor promoter $12-O$-tetradecanylphorbol13-acetate: a molecular analysis. Molecular Endocrinology 5 1983-1992.

Umayahara Y, Kawamori R, Watada H, Imano E, Iwama N, Morishima T, Yamasaki Y, Kajimoto Y \& Kamada T 1994 Estrogen regulation of the insulin-like growth factor I gene transcription involves an AP-1 enhancer. Journal of Biological Chemistry 269 16433-16442.

Vega VB, Lin CY, Lai KS, Kong SL, Xie M, Su X, Teh HF, Thomsen JS, Yeo AL, Sung WK et al. 2006 Multiplatform genome-wide identification and modeling of functional human estrogen receptor binding sites. Genome Biology 7 R82.

Vyhlidal C, Samudio I, Kladde M \& Safe S 2000 Transcriptional activation of transforming growth factor $\alpha$ by estradiol: requirement for both a GC-rich site and an estrogen response element half-site. Journal of Molecular Endocrinology 24 329-338.

Walters MR, Dutertre M \& Smith CL 2002 SKF-82958 is a subtypeselective estrogen receptor- $\alpha(\mathrm{ER} \alpha)$ agonist that induces functional interactions between ER $\alpha$ and AP-1. Journal of Biological Chemistry 277 1669-1679.

Wang W, Dong L, Saville B \& Safe S 1999 Transcriptional activation of E2F1 gene expression by $17 \beta$-estradiol in MCF-7 cells is regulated by NF-Y-Sp1/estrogen receptor interactions. Molecular Endocrinology 13 1373-1387.

Wang F, Samudio I \& Safe S 2002 Transcriptional activation of rat creatine kinase B by $17 \beta$-estradiol in MCF-7 cells involves an estrogen responsive element and GC-rich sites. Journal of Cellular Biochemistry 84 156-172.

Wang L, Wei D, Huang S, Peng Z, Le X, Wu TT, Yao J, Ajani J \& Xie K 2003 Transcription factor Spl expression is a significant predictor of survival in human gastric cancer. Clinical Cancer Research 9 6371-6380.

Weatherman RV \& Scanlan TS 2001 Unique protein determinants of the subtype-selective ligand responses of the estrogen receptors $(\mathrm{ER} \alpha$ and $\mathrm{ER} \beta)$ at AP-2 sites. Journal of Biological Chemistry 276 3827-3832.

Weatherman RV, Clegg NJ \& Scanlan TS 2001 Differential SERM activation of the estrogen receptors (ER $\alpha$ and ER $\beta)$ at AP-1 sites. Chemistry and Biology 8 427-436.

Webb P, Lopez GN, Uht RM \& Kushner PJ 1995 Tamoxifen activation of the estrogen receptor/AP-1 pathway: potential origin for the cellspecific estrogen-like effects of antiestrogens. Molecular Endocrinology 9 443-456.

Webb P, Nguyen P, Valentine C, Lopez GN, Kwok GR, McInerney E, Katzenellenbogen BS, Enmark E, Gustafsson J-Å, Nilsson S et al. 1999 The estrogen receptor enhances AP-1 activity by two distinct mechanisms with different requirements for receptor transactivation functions. Molecular Endocrinology 13 1672-1685.

Wu F, Khan S, Wu Q, Barhoumi R, Burghardt R \& Safe S 2008 Ligand structure-dependent activation of estrogen receptor $\alpha / \mathrm{Sp}$ by estrogens and xenoestrogens. Journal of Steroid Biochemistry and Molecular Biology 110 104-115. 
Xie W, Duan R \& Safe S 1999 Estrogen induces adenosine deaminase gene expression in MCF-7 human breast cancer cells: role of estrogen receptor-Sp1 interactions. Endocrinology 140 219-227.

Xie W, Duan R, Chen I, Samudio I \& Safe S 2000 Transcriptional activation of thymidylate synthase by $17 \beta$-estradiol in MCF- 7 human breast cancer cells. Endocrinology 141 2439-2449.

Yao JC, Wang L, Wei D, Gong W, Hassan M, Wu TT, Mansfield P, Ajani J \& Xie K 2004 Association between expression of transcription factor $\mathrm{Spl}$ and increased vascular endothelial growth factor expression, advanced stage, and poor survival in patients with resected gastric cancer. Clinical Cancer Research $\mathbf{1 0}$ $4109-4117$.
Zannetti A, Del VS, Carriero MV, Fonti R, Franco P, Botti G, D'Aiuto G Stoppelli MP \& Salvatore M 2000 Coordinate up-regulation of Sp1 DNA-binding activity and urokinase receptor expression in breast carcinoma. Cancer Research 60 1546-1551.

Zhao YL, Han WD, Li Q, Mu YM, Lu XC, Yu L, Song HJ, Li X, Lu JM \& Pan CY 2005 Mechanism of transcriptional regulation of LRP16 gene expression by 17- $\beta$ estradiol in MCF-7 human breast cancer cells. Journal of Molecular Endocrinology 34 77-89.

Received in final form 31 August 2008 Accepted 4 September 2008

Made available online as an Accepted Preprint 4 September 2008 